\title{
Knowledge about occupational latex allergy amongst Thai nurses and student nurses
}

\author{
Chompunuch Supapvanich, Andrew Povey, Frank de Vocht ${ }^{\#}$
}

Centre for Occupational and Environmental Health, School of Community Based Medicine, The University of Manchester, Manchester, UK; ${ }^{\#}$ Corresponding Author: frank.devocht@manchester.ac.uk

Received 22 January 2011; revised 24 April 2011; accepted 28 April 2011.

\begin{abstract}
Glove usage, particularly powdered latex glove is a cause of latex allergy in hospital workers; therefore those workers must have latex allergy knowledge to protect themselves and patients from serious health problems. This study aimed to examine knowledge about latex allergy among nurses and compare their performance with student nurses in Thailand. A knowledge questionnaire was administered to a random sample of $\mathbf{3 0}$ nurses and $\mathbf{3 0}$ student nurses who worked in hospitals where powdered latex gloves were used. Overall, nurses and student nurses gave correct responses to $27 \%$ and $28 \%$ of the questions, respectively. There was no statistically significant difference in knowledge between nurses and student nurses. Both nurses and student nurses in Thailand have insufficient knowledge about latex allergy and its risk factors. Additional continuing education should be provided to reduce the probability of adverse reactions in sensitized staff and patients in Thai hospitals.
\end{abstract}

Keywords: Latex Allergy; Education; Nurses; Student Nurses; Hospitals

\section{INTRODUCTION}

Natural rubber latex (NRL) can cause allergic symptoms in health care workers who use products containing these allergens in their daily work and it has been shown that the incidence of latex allergy in health care workers can usually be associated with exposure to latex aller-

\footnotetext{
*Funding: This work is part of a $\mathrm{PhD}$ project sponsored by the Royal Thai Government.

Competing Interests: None

Ethical approval for this study was obtained from the University of Manchester's Committee on the Ethics of Research on Human Beings (ref TPCS/ethics/08117).
}

gens encountered at the workplace [1]. The prevalence of latex allergy in health care workers ranges from $2 \%$ to $18 \%[2,3]$, whilst in the general population, the prevalence of latex allergy ranges between $0.4 \%-2.3 \%$ [4].

Exposure to natural rubber latex can result not only in skin problems such as irritant, allergic contact dermatitis, angioedema, and itchy skin [2,5], but also respiratory problems such as rhinitis, sneezing, wheezing $[3,6]$. Furthermore, it can also cause serious adverse health effects such as asthma and anaphylaxis [7]. Whilst the replacement of latex gloves with non-latex or nonpowder gloves has been shown to reduce the incidence of latex allergy [8], such measures may not be suitable in some developing countries due to their cost. For example, in Thailand, powdered latex gloves are still widely used [9]. In such situations, it has been argued that continuing education about latex allergy is essential to support the effectiveness of latex allergy prevention and control policies in hospitals [10]. Health effects of latex allergy can occur not only in health care workers but also in sensitised patients for whom they take care [11]. Thus providing latex allergy education is of importance not only for health care workers themselves but also for the health of their patients. To the best of our knowledge no study has yet reported on the levels of knowledge about latex allergy among health care workers in Thailand. The purpose of this study was to evaluate the use of a dedicated latex-knowledge questionnaire in health care workers in Thailand and subsequently to provide an indication about the level of knowledge about latex allergy-related issues among Thai nurses and student nurses.

\section{METHODS}

In this cross-sectional study, 30 nurses were randomly selected from 11 community hospitals and $303^{\text {rd }}$-year student nurses from a University in Thailand were also randomly invited to participate. The study was collected in June - July 2008. All enrolled nurses were currently 
employed in one of the hospitals, while student nurses had just finished their nursing internships in hospitals where powdered latex gloves were routinely used. All participants were asked to complete a questionnaire that evaluated their knowledge on latex allergy.

This questionnaire was developed specifically for this study and was divided in four distinct domains: 1) prevention of latex allergy, 2) potential adverse effects on health, 3) potential risk factors for latex allergy and 4) diagnosis of latex allergy. Questions were derived by the authors based on literature reviews $[5,12]$ and on the latex allergy guidelines from the National Institute for Occupational Safety and Health (NIOSH) and Health and Safety Executive (HSE) [13,14]. The questionnaire was designed so that positive and negative statements were randomly distributed in all four domains. The final version was peer reviewed by experts in the field of immunology and epidemiology. Subsequently, it was translated from English to Thai and back-translated from Thai into English by a second bilingual researcher to check for consistency and clarity of translation. Respondents were required to reply to each question on a five-point Likert scale ranging from "strongly disagree" to "strongly agree" [15]. Five-point Likert scale answers were then scored between +2 to -2 depending on whether the answer was correct or incorrect, respectively (either strongly agree $(+2)$, agree $(+1)$ or disagree $(-1)$ or strongly disagree $(-2)$, depending on the question), with the response of 'uncertain' scored as zero score. Scores from each nurse or student nurse were subsequently added up per question as well as per domain to compare group-differences in knowledge between nurses and student nurses. This implies that a participant who gave the correct answer to all questions (answering strongly agree/disagree) would have a score of 50, while someone who was incorrect at all questions (answering strongly agree/disagree) would have -50 . A Cronbach's alpha (reliability) of 0.755 was found indicating internal consistency in this knowledge questionnaire instrument.

Statistical analyses were conducted using SPSS 15.0 software for window (SPSS Inc.UK). Descriptive data analysis was used to assess the distribution of variables. Independent t-tests were used to compare the difference of knowledge scores between nurses and student nurses. A $p$-value of $5 \%$ was considered to indicate statistical significance. Bonferroni corrections were used to account for issues of multiple-comparisons [16].

\section{RESULTS}

56 of 60 respondents completed and returned the questionnaires giving a response rate of $93 \%$. There was no difference in the response rate between nurses and student nurses. The general characteristics of the re- spondents are described in Table 1. About $91 \%$ of respondents were female, which is comparable to the Thai nursing population [17]. The age of respondents ranged from 20 to 50 years with a mean age (SD) of 27.2 (7.8) years. Students were on average 7 years younger than nurses ( 27 vs. 34 , respectively). 24 of 28 nurses $(86 \%)$ graduated with a bachelor degree in nursing, with the remaining 4 (14\%) graduating with a diploma in nursing. On average, nurses had been working as nurses for 6 years, ranging from 3 months to 26 years. $90.4 \%$ of respondents wore powdered latex gloves in their work shifts $(80 \%$ and $100 \%$ for nurses and students, respectively), using on average $5.5(\mathrm{SD}=3.7)$ pairs per day.

Group knowledge scores were normally distributed. The mean knowledge assessment scores of all respondents was $-0.04(\mathrm{SD}=0.16)$ (Table 2). A comparison of mean scores between both groups of nurses and student nurses showed that there were no significant difference in latex allergy knowledge $(p=0.71)$. None of the mean knowledge scores for domains D1 to D4 differed significantly from zero, and were $-0.09,-0.05,0.20$, and -0.65 for domains D1 to D4, respectively. The participants knew the least about issues related to the diagnosis of latex allergy (D4) with only $1.8 \%$ and $5.4 \%$ of questions answered correctly by the nurses and student nurses (Table 3), respectively. The highest number of correct answers was found for questions addressing potential risk factors for latex allergy (D3) (34.5\% in nurses and $37 \%$ in student nurses, respectively).

No Statistically significant differences were found between nurses and student nurses in any of the domains.

Overall, 28\% of answers were correcting answer, but the majority of questions $(41 \%)$ were answered as "Do not know" (Table 3). Over 50\% of all respondents gave a correct answer on "Screening can assist to identify latex allergy" (question 1), "Atopic individual have risk to develop latex allergy" (question 9), and "Instruments such as syringes, air ways, endotracheal tubes and oxygen tubing contain latex allergens" (question 24).

However, knowledge was low, with less than $25 \%$ of respondents giving a correct answer, on the following questions;

Q3. The room must be clean and the air allowed to settle for at least 6 hours before latex allergy patients are admitted.

Q11. Skin irritation to latex gloves is a result from an immune response.

Q13. Latex allergy can be diagnosed by clinical symptoms only.

Q14. The patch test is a common investigation method in latex allergy (immediate hypersensitivity).

Q16. Diagnosis of immediate hypersensitivity to latex 
can be confirmed by skin prick test, blood test, wear test of a patch test.

Q23. Chemicals in latex gloves can induce respiratory symptoms in health care workers.

A comparison of the proportion of correct answers for each question between nurses and student nurses suggested statistically significant differences for questions 1 and $19(p<0.05)$. As a group, student nurses seemed to better than nurses in identifying that screening can assist in identification of latex allergic patients (question 1) $(p$ $<0.01$ ), while more nurses gave a correct answer regarding adverse symptoms to latex allergens (question 19) $(p<0.05)$. However, adjusting for multiple comparisons none of these remained statistically significant.

Table 1. Personal status between response nurses and student nurses in thailand $(n=56)$.

\begin{tabular}{|c|c|c|c|}
\hline Variable & Total Number (\%) & Nurses (\%) & Student Nurses (\%) \\
\hline Study Population (\% Response Rate) & $56(93.3)$ & $28(93.3)$ & $28(93.3)$ \\
\hline \multicolumn{4}{|l|}{ Gender } \\
\hline Female & $51(91.1)$ & $28(100)$ & $23(82.1)$ \\
\hline Male & $5(8.9)$ & 0 & $5(17.9)$ \\
\hline Age $($ Mean \pm SD) & $27.2 \pm 7.8$ & $33.5 \pm 6.4$ & $20.9 \pm 0.5$ \\
\hline $20-29$ Years & $32(57.1)$ & $4(14.3)$ & $28(100.0)$ \\
\hline $30-39$ Years & $18(5.3)$ & $18(64.3)$ & 0 \\
\hline$\geq 40$ Years & $6(28.6)$ & $6(21.4))$ & 0 \\
\hline \multicolumn{4}{|l|}{ Ethnic } \\
\hline Thai & $40(71.4)$ & $12(42.9)$ & $28(100.0)$ \\
\hline Thai-Malaysian & $16(28.6)$ & $16(57.1)$ & 0 \\
\hline \multicolumn{4}{|l|}{ Education } \\
\hline Bachelor & $52(92.9)$ & $24(85.7)$ & $28(100.0)$ \\
\hline Diploma & $4(7.1)$ & $4(14.3)$ & 0 \\
\hline Work/Internship Experience (Mean \pm SD) & $6.1 \pm 7.3$ & $6.02 \pm 7.46$ & $0.49 \pm 1.07$ \\
\hline$\leq 10$ Years & $35(62.5)$ & $7(25)$ & $28(100)$ \\
\hline$\geq 10$ Years & $21(37.5)$ & $21(75)$ & 0 \\
\hline \multicolumn{4}{|l|}{ Use of Powdered Latex Gloves $(\mathrm{n}=52)$} \\
\hline No & $5(9.6)$ & $5(20.8)$ & 0 \\
\hline Yes & $47(90.4)$ & $19(79.2)$ & $28(100)$ \\
\hline Number of Powdered Gloves $(n=47)($ Mean \pm SD $)$ & $5.5 \pm 3.7$ & $6.1 \pm 4.6$ & $5.3 \pm 2.9$ \\
\hline 1 - 5 Pairs per Day & $29(61.7)$ & $10(52.6)$ & $19(67.9)$ \\
\hline$>5$ Pairs per Day & $18(38.3)$ & $9(47.4)$ & $9(32.1)$ \\
\hline
\end{tabular}

Table 2. Comparison of mean scores (two-sample t-test) on latex allergy knowledge between nurses and student nurses.

\begin{tabular}{lcccc}
\hline \multirow{2}{*}{ Knowledge Domain } & \multicolumn{3}{c}{ Mean Score ( \pm SD) } & 95\% CI \\
\cline { 2 - 4 } Overall & Total & Nurses & Student Nurses \\
D1. Prevention of Latex Allergy & $-0.04( \pm 0.16)$ & $-0.04( \pm 0.15)$ & $-0.05( \pm 0.17)$ & -0.10 to 0.07 \\
D2. Potential Adverse Effects on Health & $-0.09( \pm 0.27)$ & $-0.11( \pm 0.25)$ & $-0.06( \pm 0.28)$ & -0.10 to 0.18 \\
$\begin{array}{l}\text { D3. Potential Risk Factors for Latex Allergy } \\
\text { D4. Diagnosis of Latex Allergy }\end{array}$ & $0.20( \pm 0.29)$ & $0.21( \pm 0.25)$ & $0.19( \pm 0.33)$ & -0.17 to 0.14 \\
\hline
\end{tabular}


Table 3. Percentages of correct, incorrect and unknown answers and "knowledge scores" for each question in the questionnaire, stratified for nurses $(n=28)$ and student nurses $(n=28)$.

\begin{tabular}{|c|c|c|c|c|c|c|c|c|c|c|c|c|}
\hline \multirow[b]{2}{*}{ Items } & \multicolumn{3}{|c|}{ Correct (\%) } & \multicolumn{3}{|c|}{ Wrong (\%) } & \multicolumn{3}{|c|}{ Don't Know (\%) } & \multicolumn{2}{|c|}{ Mean Score } & \multirow{2}{*}{$\begin{array}{c}\text { Two-sample } \\
\text { t-test } \\
\text { P - value } \\
<0.05^{1}\end{array}$} \\
\hline & Total & nurses & $\begin{array}{c}\text { Student } \\
\text { nurses }\end{array}$ & Total & Nurses & $\begin{array}{c}\text { Student } \\
\text { nurses }\end{array}$ & Total & nurses & $\begin{array}{c}\text { Student } \\
\text { nurses }\end{array}$ & Nurses & $\begin{array}{c}\text { Student } \\
\text { nurses }\end{array}$ & \\
\hline Overall & 28.0 & 27.6 & 28.4 & 33.1 & 32.1 & 34.1 & 39.0 & 40.4 & 37.6 & & & \\
\hline D1: Prevention of Latex Allergy & 23.3 & 23.0 & 23.5 & 29.8 & 27.5 & 32.1 & 46.7 & 49.0 & 44.4 & -0.04 & -0.05 & \\
\hline $\begin{array}{l}\text { 1. Screening can assist health care workers to } \\
\text { identify an allergic patient. }\end{array}$ & 82.1 & 67.9 & 96.4 & 5.4 & 10.7 & 0 & 12.5 & 21.4 & 3.6 & 0.71 & 1.43 & $* *$ \\
\hline $\begin{array}{l}\text { 2. A latex sensitized patient should be first on } \\
\text { the operation list. }\end{array}$ & 25.0 & 14.3 & 35.7 & 26.8 & 32.1 & 21.4 & 48.2 & 53.6 & 42.9 & -0.29 & 0.14 & \\
\hline $\begin{array}{l}\text { 3. The room must be clean and the air al- } \\
\text { lowed settle for at least } 6 \text { hours before pa- } \\
\text { tients with latex allergy are admitted.* }\end{array}$ & 16.1 & 28.6 & 3.6 & 53.6 & 57.1 & 50.0 & 30.4 & 14.3 & 46.4 & -0.32 & -0.68 & \\
\hline $\begin{array}{l}\text { 5. "Hypoallergenic gloves" can reduce latex } \\
\text { allergy in health care workers.* }\end{array}$ & 3.6 & 7.1 & 0 & 44.6 & 25.0 & 64.3 & 50 & 64.3 & 35.7 & -0.64 & -0.75 & \\
\hline $\begin{array}{l}\text { 8. Nitrile gloves can induce latex sensitisa- } \\
\text { tion in health care workers.* }\end{array}$ & 5.4 & 3.6 & 7.1 & 21.4 & 17.9 & 25.0 & 73.2 & 78.6 & 67.9 & -0.14 & -0.18 & \\
\hline $\begin{array}{l}\text { 18. The use of powder free glove is a way of } \\
\text { reducing latex allergy in health care workers. }\end{array}$ & 30.4 & 39.3 & 21.4 & 16.1 & 7.1 & 25.0 & 53.6 & 53.6 & 53.6 & 0.32 & 0 & \\
\hline $\begin{array}{l}\text { 21. Nitrile gloves and vinyl gloves contain } \\
\text { latex allergens.* }\end{array}$ & 0 & 0 & 0 & 41.1 & 42.9 & 39.3 & 58.9 & 57.1 & 60.7 & -0.43 & -0.50 & \\
\hline D2: Potential adverse effects on health & 33.6 & 34.5 & 32.7 & 32.7 & 33.3 & 32.1 & 33.3 & 31.5 & 35.1 & -0.02 & -0.08 & \\
\hline $\begin{array}{l}\text { 4. Latex allergic reactions cannot develop to } \\
\text { be potential life-threatening.* }\end{array}$ & 50.0 & 42.9 & 57.1 & 16.1 & 25.0 & 7.1 & 33.9 & 32.1 & 35.7 & 0.25 & 0.61 & \\
\hline $\begin{array}{l}\text { 11. Skin irritation to latex gloves is a reac- } \\
\text { tion that results from an immune response. * }\end{array}$ & 3.6 & 3.6 & 3.6 & 83.9 & 82.1 & 85.7 & 12.5 & 14.3 & 10.7 & -0.86 & -1.11 & \\
\hline $\begin{array}{l}\text { 17. Allergic symptoms to latex usually occur } \\
\text { within six hours.* }\end{array}$ & 16.1 & 17.9 & 14.3 & 39.3 & 39.3 & 39.3 & 44.6 & 42.9 & 46.4 & -0.25 & -0.32 & \\
\hline $\begin{array}{l}\text { 19. Bronchospasm, hypotension and cardiac } \\
\text { arrest can occur in latex sensitised individu- } \\
\text { als. }\end{array}$ & 58.9 & 75.0 & 39.3 & 12.5 & 3.6 & 21.4 & 30.4 & 21.4 & 39.3 & 0.89 & 0.29 & $* *$ \\
\hline $\begin{array}{l}\text { 22. Delayed hypersensitivity is caused by } \\
\text { exposure to chemicals used in latex gloves. }\end{array}$ & 42.9 & 42.9 & 39.3 & 7.1 & 3.6 & 10.7 & 50 & 50.0 & 50.0 & 0.43 & 0.36 & \\
\hline $\begin{array}{l}\text { 25. Latex allergic reactions can occur in latex } \\
\text { sensitive workers if they work with col- } \\
\text { leagues who wear latex gloves. }\end{array}$ & 33.9 & 25.0 & 42.9 & 37.5 & 46.4 & 28.6 & 28.6 & 28.6 & 28.6 & -0.21 & 0.11 & \\
\hline D3: Potential risk factors for latex allergy & 35.7 & 34.5 & 36.9 & 20.4 & 15.9 & 25.0 & 43.8 & 49.6 & 38.1 & 0.21 & 0.19 & \\
\hline $\begin{array}{l}\text { 6. Latex proteins are a main cause of latex } \\
\text { sensitisation. }\end{array}$ & 37.5 & 35.7 & 39.3 & 5.4 & 0 & 10.7 & 57.1 & 64.3 & 50.0 & 0.36 & 0.36 & \\
\hline $\begin{array}{l}\text { 7. Individuals with an allergy to soy milk or } \\
\text { cow milk can develop an allergic cross reac- } \\
\text { tion to latex products.* }\end{array}$ & 16.1 & 7.1 & 25.0 & 12.5 & 14.3 & 10.7 & 71.4 & 78.6 & 64.3 & -0.07 & 0.14 & \\
\hline $\begin{array}{l}\text { 9. Atopic individuals have a high risk of } \\
\text { developing latex allergy. }\end{array}$ & 71.4 & 78.6 & 64.3 & 12.5 & 3.6 & 21.4 & 16.1 & 17.9 & 14.3 & 0.79 & 0.64 & \\
\hline $\begin{array}{l}\text { 10. Spina bifida patients have a high risk of } \\
\text { developing latex allergy. }\end{array}$ & 35.7 & 32.1 & 39.3 & 10.7 & 7.1 & 14.3 & 53.6 & 60.7 & 46.4 & 0.25 & 0.46 & \\
\hline $\begin{array}{l}\text { 12. Grass pollen allergy is associated with } \\
\text { latex sensitisation. }\end{array}$ & 28.6 & 32.1 & 25.0 & 28.6 & 17.9 & 39.3 & 42.9 & 50.0 & 35.7 & 0.18 & -0.04 & \\
\hline $\begin{array}{l}\text { 15. Individuals who are allergic to fruits such } \\
\text { as banana, mango, or papaya have an in- } \\
\text { creased risk of developing latex allergy. }\end{array}$ & 33.9 & 39.3 & 28.6 & 19.6 & 17.9 & 21.4 & 46.4 & 42.9 & 50.0 & 0.25 & 0.14 & \\
\hline
\end{tabular}




\begin{tabular}{|c|c|c|c|c|c|c|c|c|c|c|c|}
\hline $\begin{array}{l}\text { 20. Multiple operations increase the risk of } \\
\text { latex allergy in the patient. }\end{array}$ & 25.0 & 21.4 & 28.6 & 26.8 & 14.3 & 39.3 & 48.2 & 64.3 & 32.1 & 0.11 & -0.07 \\
\hline $\begin{array}{l}\text { 23. Chemicals in latex gloves can induce } \\
\text { respiratory symptoms in health care work- } \\
\text { ers.* }\end{array}$ & 5.4 & 3.6 & 7.1 & 55.4 & 57.1 & 53.6 & 39.3 & 39.3 & 39.3 & -0.57 & -0.64 \\
\hline $\begin{array}{l}\text { 24. Instruments such as syringes, air ways, } \\
\text { endotracheal tubes and oxygen tubing con- } \\
\text { tain latex allergens. }\end{array}$ & 67.9 & 60.7 & 75.0 & 12.5 & 10.7 & 14.3 & 19.6 & 28.6 & 10.7 & 0.61 & 0.75 \\
\hline D4: Diagnosis of latex allergy & 3.6 & 1.8 & 5.4 & 71.4 & 72.6 & 71.4 & 33.7 & 21.4 & 23.2 & -0.63 & -0.68 \\
\hline $\begin{array}{l}\text { 13. Latex allergy can be diagnosed by clini- } \\
\text { cal symptoms only.* }\end{array}$ & 5.4 & 0 & 10.7 & 78.6 & 82.1 & 75.0 & 9 & 17.9 & 14.3 & -0.89 & -0.89 \\
\hline $\begin{array}{l}\text { 14. The patch test is a common investigation } \\
\text { method in latex allergy (immediate hyper- } \\
\text { sensitivity).* }\end{array}$ & 1.8 & 3.6 & 0 & 69.6 & 71.4 & 67.9 & 28.6 & 25.0 & 32.1 & -0.75 & -0.82 \\
\hline $\begin{array}{l}\text { 16. Diagnosis of immediate hypersensitivity } \\
\text { to latex can be confirmed by skin prick test, } \\
\text { blood test, wear test or a patch test.* }\end{array}$ & 3.6 & 3.6 & 3.6 & 66.1 & 64.3 & 67.9 & 30.4 & 32.1 & 28.6 & -0.64 & -0.75 \\
\hline
\end{tabular}

*Negative question. $P$-value of difference between nurses and student nurse based on summary scores $($ Table 2$)$, ** statistics significant level $<0.05(P$-value adjustment (Bonferroni correction) $=0.002$ ).

These data further suggest some remarkable gaps in knowledge regarding risk factors for latex allergy. Most notably, none of the participants knew that nitrile gloves and vinyl gloves do not contain latex allergens (question $21)$. Also, none of the students (and only 7\% of nurses) were familiar with "hypoallergenic gloves" (question 5), while all nurses (and only $11 \%$ of students) thought that latex allergy could be diagnosed based on clinical symptoms only (question 13).

In addition, these analyses further suggest that several questions (questions $6,7,8,18,21$ ) were very difficult for nurses or student nurses to answer with the majority $(>50 \%)$ of the nurses and student nurses answering "Don't know" to these questions. Overall, the results in this study suggest that $62 \%$ of study population (33\% of respondents giving wrong answers and 39\% of respondents giving "do not know" answers) had insufficient knowledge about latex allergy.

\section{DISCUSSION}

Results from this study suggest that both nurses and student nurses had insufficient knowledge about latex allergy and that no statistically significant differences were observed between knowledge levels of nurses and student nurses. This finding is similar to that found in other countries [18-20]. Nurses who were allergic to latex on average have been shown to have less knowledge about latex allergy knowledge than nurses who were not allergic [18]. This association might also be presented in this study, but allergic status was not determined in this study. However, it is possible that inadequate knowledge about latex allergy and risk factors may lead to the development of serious adverse symptoms in sensitized nurse, a suggestion made previously [18].

Although most of the students in this population (75\%) knew that instruments such as syringes, air ways, endotracheal tubes and oxygen tubing contain latex allergens, surprisingly, only $21 \%$ knew that the use of powder free gloves can reduce latex allergy in health care workers, while none of the nurses or students knew that nitrile gloves and vinyl gloves did not contain any latex proteins at all. Opposite results were found in a study in Turkey [20] which showed that whereas all Turkish medical students knew that gloves may contain latex allergens, as many as $82 \%$ were not aware that medical instruments such as catheters, surgical materials, intravenous lines, and syringes could also contain latex allergens. We speculate that these differences are either caused by differences in education in both countries or by methodological differences in the way the questions were asked, although which of these hypotheses is valid cannot be proven.

Also, although over $80 \%$ of students in our study knew that NRL can cause allergy, less than $8 \%$ were familiar with the fact that the NRL can cause both immediate hypersensitivity (type I) and delayed hypersensitivity (type IV). This is comparable to the data from Turkey, where $84.8 \%$ of medical students knew that avoidance of exposure to NRL products is a protection method and $15.8 \%$ knew that wearing vinyl gloves before wearing latex gloves can prevent the direct contact with latex proteins [20].

This study provides data specifically for the health care industry in Thailand and, in agreement with data from other countries discussed above, suggests that additional and continuing training should be provided to student nurses as well as to nurses to reduce the risk of 
personnel and patients for becoming sensitised or develop latex allergy. This is in agreement with recommendations from NIOSH who recommended that workers should receive education programs and training materials about latex allergy [13]. Furthermore, HSE also recommended that employers and healthcare providers should be education on NRL allergy and risk factors [14]. A study in Sweden reported an improvement in knowledge about latex allergy-related topics in nurses who received a special training program, although after this one-off program the score remained inadequate providing additional argumentation for continuing education [19].

It has been suggested that additional training should be focussed on three groups. Firstly, sensitised individuals should be educated on conditions and latex allergy avoidance and prevention. Secondly, workers, particularly health care workers, who are at risk of latex allergy, should be educated about latex allergy and prevention of latex allergy as well as about latex-free alternative instruments. Finally, latex allergy education, particularly latex allergy prevention policies and latex safety in workplaces for latex sensitised individuals, should be provided to employers [21].

\section{CONCLUSIONS}

In conclusion, the finding of this study indicate that nurses working in community-based hospitals in Thailand as well as Thai student nurses have a similar education level regarding latex allergy in the workplace and its risk factors, and that this level at present is insufficient in both groups. Additional latex allergy education and training should be provided to student nurses during their degrees and this should be continued during their professional lives. Education training programs should not be limited to general information about latex allergy but should also focus on reducing latex allergens in the workplace environment.

\section{ACKNOWLEDGEMENTS}

The authors would like to thank all nurses and student nurses participated in this study. Furthermore, we would like to thank Miss Kanokporn Boripat from Saiburi Hospital and Mrs. Supaluk Toulamoon, from the Naresuan University for their help.

\section{REFERENCES}

[1] Archambault, S., Malo, J.L., Infante-Rivard, C., Ghezzo, H. and Gautrin, D. (2001) Incidence of sensitization, symptoms, and probable occupational rhinoconjunctivitis and asthma in apprentices starting exposure to latex. Journal of Allergy and Clinical Immunology, 107, 921923. doi:10.1067/mai.2001.114116
[2] Chaiear, N., Jindawong, B., Boonsawas, W., Kanchanarach, T. and Sakunkoo, P. (2006) Glove allergy and sensitization to natural rubber latex among nursing staff at Srinagarind hospital, Khon Kaen, Thailand. Journal of the Medical Association of Thailand, 89, 368-376.

[3] Diéquez, M.C., Pulido, Z., Hoz, de la B., Blanco, R., Cerecedo, I., Fernández-Caldes, E. and Swanson, M. (2007) Latex allergy in healthcare workers: An epidemiological study in a Spanish hospital. Allergy and Asthma Proceedings, 28, 564-570.

doi:10.2500/aap2007.28.3036

[4] Bousquet, J., Flahault, A., Vandenplas, O., Ameille, J., Duron, J.J., Pecquet, C., Chevrie, K. and Annesi-Maesano, I. (2006) Natural rubber latex allergy among health care workers: A systematic review of the evidence. Journal of Allergy and Clinical Immunology, 118, 447-454. doi:10.1016/j.jaci.2006.03.048

[5] Reddy, S. (1998) Latex allergy. American Family Physician, 57, 1-11.

[6] Archambault, S., Malo, J.L., Infante-Rivard, C., Ghezzo, H. and Gautrin, D. (2001) Incidence of sensitization, symptoms, and probable occupational rhinoconjunctivitis and asthma in apprentices starting exposure to latex. Journal of Allergy and Clinical Immunology, 107, 921923. doi:10.1067/mai.2001.114116

[7] Sussman, G.L., Liss, G.M., Deal, K., Brown, S., Cividino, M., Siu, S., Beezhold, D.H., Smith, G., Swanson, M.C., Yunginger, J., Douglas, A., Holness, D.L., Lebert, P., Keith, P., Waserman, S. and Turjanmaa, K. (1998) Incidence of latex sensitization among latex glove users. Journal of Allergy and Clinical Immunology, 101, 171178. doi:10.1016/S0091-6749(98)70381-1

[8] Allmers, H., Brehler, R., Chen, Z., Raulf-Heimsort, M., Fels, H. and Baur, X. (1998) Reduction of latex aeroallergens and latex-specific IgE antibodies in sensitized workers after removal of powdered natural rubber latex gloves in a hospital. Journal of Allergy and Clinical Immunology, 102, 841-846.

doi:10.1016/S0091-6749(98)70026-0

[9] Danchaivijitr, S., Suwanasuthi, P., Cherdrungsi, R. and Tuntiwattanapibul, Y. (2005) A study on powdering of reusable surgical gloves. Journal of the Medical Association of Thailand, 88, S188-S191.

[10] Dakin, M.J. and Yentis, S.M. (1998) Latex allergy: A strategy for management. Anaesthesia, 53, 774-781. doi:10.1046/j.1365-2044.1998.00531.x

[11] Raulf-Heimsoth, M., Rihs, H.P., Rozynek, P., Cremer, R., Gaspar, A., Pires, G., Yeang, H.Y., Arif, S.A., Hamilton, R.G., Sander, I., Lundberg, M. and Brüning, T. (2007) Quantitative analysis of immunoglobulin E reactivity profiles in patients allergic or sensitized to natural rubber latex (Hevea brasiliensis). Clinical \& Experimental Allergy, 37, 1657-1667. doi:10.1111/j.1365-2222.2007.02833.x

[12] Association of Operating Room Nurses (2004) AORN latex guideline. AORN Journal, 79, 653-672. doi:10.1016/S0001-2092(06)60918-6

[13] National Institute for Occupational Safety and Health (1997) NIOSH Alert: Preventing allergic reactions to natural rubber latex in the workplace. National Institute for Occupational Safety and Health DHHS [NIOSH] Publication, 97-135. http://www.cdc.gov/niosh/latexalt.html 
[14] Health and Safety Executive (HSE) (2008) About latex allergies. http://www.hse.gov.uk/latex/about.htm

[15] Bond, T.G. and Fox, C.M. (2007) Measurement using likert scales. In: Bond, T.G. and Fox, C.M., Eds, Applying the Rasch Model, Fundamental Measurement in the Human Science, 2nd Edition, Lawrence Eribaum Associates, Mahwah, pp. 101-122.

[16] Bland, J.M. and Altman, D.G. (1995) Multiple significance tests: The Bonferroni method. BMJ, 310, 170.

[17] Ekintumas, D. (1999) Nursing in Thailand: Western concepts vs Thai tradition. International Nursing Review, 46, 55-57. doi:10.1046/j.1466-7657.46.no2issue344.16.x

[18] Lewis, L., Norgan, G. and Reilly, M. (1998) Are nurses knowledgeble in regards to latex allergy? Semin Perioper Nurs, 7, 239-253.
[19] Bundesen, I. (2008) Natural rubber latex: A matter of concern for nurses. AORN Journal, 88, 197-210. doi:10.1016/j.aorn.2008.02.003

[20] Erkekol, F.O., Celik, G.E., Hayran, M., Dursun, B.A., Göksel, O.K., Misirligil, M.S. and Demirel, Y.S. (2008) The prevalence of latex allergy in sixth year medical students: assessment of knowledge, risk and attitudes about future specialty direction. Annals of Allergy, Asthma \& Immunology, 100, 576-582. doi:10.1016/S1081-1206(10)60057-9

[21] Binkley, H.M., Schroyer, T. and Catalfano, J. (2003) Latex allergies: A review of recognition, evaluation, management, prevention, education and alternative product use. Journal of Athletic Training, 38, 133-140. 